\title{
Assessment of the Impact of Petroleum Depot Effluents on a Nearby River Quality
}

\author{
Nasir Abdus-Salam (Ph. D-Professor) \\ Olamide Sodiq Ademola (M.Sc.) \\ Mojeed Olalekan Bello (M.Sc.)
}

Department of Chemistry, University of Ilorin, Ilorin, Nigeria

Doi: 10.19044/esj.2017.v13n36p396 URL:http://dx.doi.org/10.19044/esj.2017.v13n36p396

\begin{abstract}
The possible effects of the petroleum depot effluents on the river water quality were examined. Twelve-monthly water sampling (June, 2015 to May, 2016) were taken from upstream and downstream of the river. Physicochemical parameters such as $\mathrm{pH}$, temperature, turbidity, total dissolved solid (TDS), total suspended solid (TSS), total solid (TS), biochemical oxygen demand (BOD), dissolved oxygen (DO), total alkalinity, electrical conductivity (EC), total hardness, phosphate, sulphate, nitrate, chloride and heavy metals were determined using standard methods. The $\mathrm{pH}$, temperature, TDS, TSS, TS, BOD, total alkalinity and chloride concentrations exceeded the guidelines values of WHO, SON and EPA during the dry season and within the permissible limits during the rainy season. The EC, total hardness, sulphate and nitrate were within the range of standards while phosphate and turbidity exceeded the permissible standard values throughout the sampling period. Pearson correlation coefficient of ions showed that there was a significant correlation at the 0.01 probability level. Therefore, the metals and anions are from a common source. Atomic Absorption Spectrophotometric results showed that concentration of $\mathrm{Cd}$ and $\mathrm{Ni}$ exceeded standard values, 0.005 and $0.1 \mathrm{mg} / \mathrm{L}$ respectively during the dry season while $\mathrm{Pb}$ and $\mathrm{Cr}$ exceeded the permissible limits, 0.01 and $0.05 \mathrm{mg} / \mathrm{L}$ during the rainy season. Copper was within the permissible limit $0.5 \mathrm{mg} / \mathrm{L}$ while $\mathrm{Zn}$ exceeded the permissible limit $0.05 \mathrm{mg} / \mathrm{L}$ throughout sampling periods. The levels of $\mathrm{Pb}, \mathrm{Cd}, \mathrm{Zn}, \mathrm{Ni}$, and $\mathrm{Cr}$ in the river are particularly high enough to cause public concerns.
\end{abstract}

Keywords: Heavy metals, Pearson correlation, permissible limits, physicochemical parameters, $\%$ violation 


\section{Introduction}

Petroleum depots are generally located in the remote areas (OISD, 2012). Experience shows that with the passage of time, it gets surrounded by residential and/or industrial installations due to possible gains. However, as human dependency on crude-oil increases the dangers that accompanied it also increases (Abdus-Salam et al. 2010). Leakages and spills associated with loading and offloading of petroleum products in these depots as well as washing of oil storage tanks has adverse impact on the environment (Rasmussen, 1976). The indiscriminate discharge of effluents by the petroleum depot into the environment causes degradation of the aquatic ecosystem located near their installations. Crude oil is a complex mixture of several polycyclic aromatic compounds, heavy metals, anions, other hydrocarbons and additives. Nigeria crude oils were studied and shown to contain relatively high concentrations of some heavy metals, $\mathrm{Fe}, \mathrm{Zn}, \mathrm{Cu}$ and $\mathrm{Pb}$ (Owamah, 2013). The refined petroleum products show higher toxicity compared to crude oil since metal speciation is altered and new metals added to the matrix during the refining processes (Uzoekwe and Oghosanine, 2011).

Ever since the beginning of the existence of the universe, water has been an inevitable resource to all living things on earth. Although, water is abundant on earth in the form of oceans, seas, rivers, lakes and wells, large proportion of this water is not in the state suitable for human or animal consumption (Giwa et al. 2009). Water pollution is a serious problem for the entire world. All water pollution is dangerous to the health of living organisms, but sea and river pollution can be especially detrimental to the health of humans and animals. Rivers and seas are used as primary sources of potable water by populations all over the world (Mbaneme et al. 2013). Industrial wastewaters are continually being discharged indiscriminately into surface waters resulting in impairment of water quality (Sarkodie et al. 2014). This has led to pure and hygienic water scarcity, disruption of socioeconomic activities and poor aesthetic quality of most of the water bodies polluted by the industrial activities.

It had been observed that toxicity from oil pollution can lead to respiratory illness, kidney disease, neurological diseases etc in humans (Ndubuisi and Asia, 2007). Effluents from petroleum companies are one of the largest sources of water pollution and one with the most lethal composition of toxins (Mishra and Jhansi, 2013). The waters that are being in contact with petroleum and its derivatives contain oil, hydrocarbons, sulfides, ammonia and large quantities of inorganic salts (Mukherjee et al. 2011). As a result, these toxic substances shift from one compartment within the aquatic environment to another including the biota often with detrimental effects, through sufficient bioaccumulation. They accumulate and are passed 
on at successive greater concentration of predators higher up in the food chain (Akporido and Asagba, 2013). It became necessary to carry out environmental assessment of the water of the area suspected of receiving the pollutant from the point of discharge from time to time, in order to evaluate the level of contaminants and to know the remediation techniques to implore in the purification of affected environments.

\section{Materials and Methods}

\section{Study area}

The oil depot studied (Table1) is located between latitude ( $\left.8^{\circ} 34^{\prime} 60^{\prime \prime}\right)$ $\mathrm{N}$ and longitude (443'0") $\mathrm{E}$ in Oke-Oyi, Ilorin East local government area, Kwara State, Nigeria. The sampling locations map (upstream and downstream), latitude and longitude were recorded using global positioning system (GPS) and Google earth (Figure 1).

Table 1: Sampling points and locations.

\begin{tabular}{ccc}
\hline \multirow{2}{*}{ Sampling points } & \multicolumn{2}{c}{ Location } \\
\cline { 2 - 3 } & Latitude & Longitude \\
\hline Upstream & $8^{\circ} 34^{\prime} 4.40^{\prime \prime} \mathrm{N}$ & $4^{\circ} 41^{\prime} 2.75^{\prime \prime} \mathrm{E}$ \\
Downstream & $8^{\circ} 33^{\prime} 33.34^{\prime \prime} \mathrm{N}$ & $4^{\circ} 41^{\prime} 33.52^{\prime \prime} \mathrm{E}$ \\
\hline
\end{tabular}

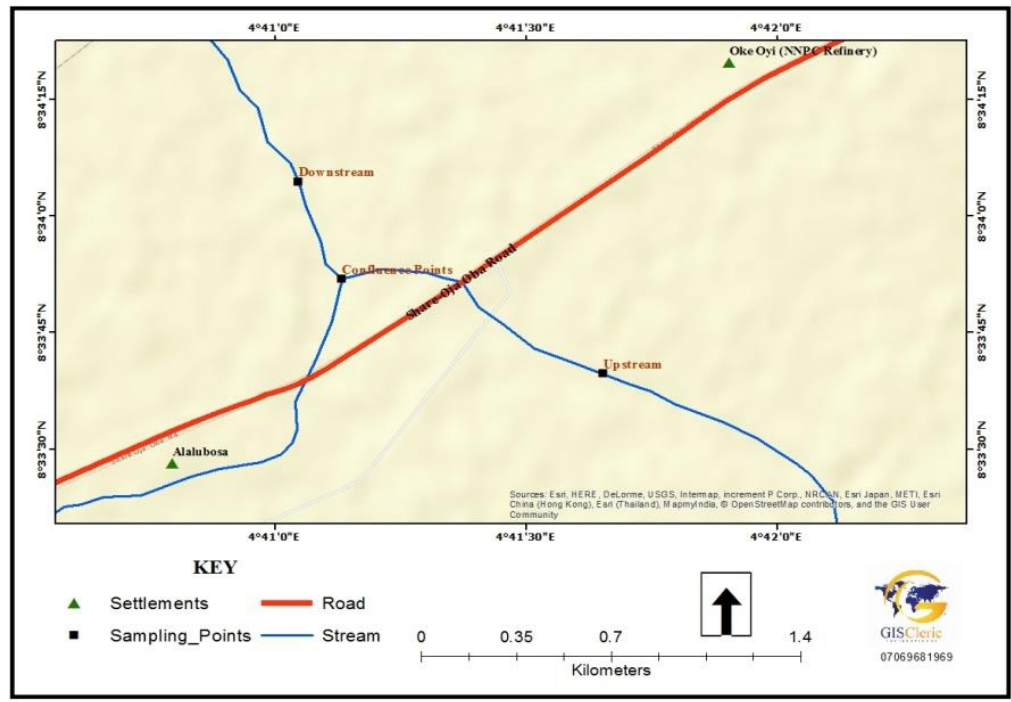

Figure 1: Map showing sampling points

\section{Sampling and preservation}

Water samples were collected from the upstream and downstream of the river into $1 \mathrm{~L}$ high density polyethylene (HDPE) plastic vials pre-treated with $4 \mathrm{M} \mathrm{HNO}_{3}$ and properly rinsed with de-ionized water followed by doubly distilled water before use. Water samplings were carried out on 
monthly basis for 12 months between June, 2015 and May, 2016. Samples for metals analysis were collected separately and preserved immediately with 2 mL concentrated $\mathrm{HNO}_{3}$ per $1 \mathrm{~L}$ sample. Samples handling and preservation were carried out in accordance with standard methods (APHA, 1995).

\section{Water analysis}

The $\mathrm{pH}$, temperature, turbidity and conductivity of the water samples were measured with $\mathrm{pH}$-meter, thermometer, turbidimeter and conductivity meter respectively which were previously calibrated before use. These parameters were determined in situ immediately after samples were collected. The total dissolved solid (TDS), Total suspended solid (TSS), total solid (TS), Dissolved oxygen (DO), Biochemical oxygen demand (BOD), Total alkalinity (TA) and Total hardness (TH) were determined using standard methods. Chloride, nitrate, sulphate and phosphate concentrations were determined by Mohr's, sodium salicylate (colorimetric), turbidimetric and ascorbic acid methods respectively (APHA-AWWA \& WEF, 2005). Water samples were digested with aqua regia, $\mathrm{HCl} / \mathrm{HNO}_{3}$ (3:1) to release metals in a measurable form by atomic absorption spectrophotometer (APHA-AWWA \& WEF, 2005).

\section{Data analysis}

Data obtained from physical and chemical measurements were subjected to descriptive statistical analysis, Pearson correlation coefficient and Box plot analyses. The mean values were compared with the water quality criteria of World Health Organization (WHO), Standard Organisation of Nigeria (SON) and Environmental Protection Agency (EPA). The Pearson correlation coefficient $(\mathrm{P}<0.01)$ and Box plot analyses were used to establish relationship trend between parameters, pollution sources and the extent of the petroleum depot effluents into the river.

\section{Results and Discussion}

The average values of physicochemical parameters determined in this study are reported in Table $\mathbf{2}$ for the two sampling points. The values obtained were compared to WHO, EPA and SON standards in order to obtain the percentage violation reported in Figure 2. The $\mathrm{pH}$ values ranged from 4.2 to 7.8 for upstream with a mean value of $6.4 \pm 1.17$ while the downstream ranged from 5.1 to 8.5 with an average of $7.05 \pm 0.79$. Both sampling points have low $\mathrm{pH}$ during the dry season and early rainy season with $50-100 \%$ percentage violation compared to the rainy season. This difference could be attributed to the presence of acidic constituents of water resulting from the microbial utilization of hydrocarbon pollutants in the ecosystem studied (Antai et al. 2016). According to Swingle (2000), organic 
waste reduces the $\mathrm{pH}$ of water and sediment to acidic level. It was observed that the temperature of the river water reduces with increase in the amount of rainfall. Temperature ranged from 24.5 to $37{ }^{\circ} \mathrm{C}$ with a mean temperature of the upstream as $29.45 \pm 3.98{ }^{\circ} \mathrm{C}$ while the downstream mean temperature was $29.79 \pm 3.61{ }^{\circ} \mathrm{C}$. The fluctuation in river water temperature usually depends on the season, geographic location, sampling time and temperature of effluents entering the stream (Flura et al. 2016). The total dissolved solid (TDS), total suspended solid (TSS) and total solid (TS) for all the sampling points have no violation during the rainy season whereas, the values for the dry season varied from $50 \%$ to $100 \%$ violation of the standard values. The TDS for upstream ranged from 38 to $2125 \mathrm{mg} / \mathrm{L}$ with an average of $508.02 \pm$ $409.16 \mathrm{mg} / \mathrm{L}$ while the downstream ranged from 40 to $1300 \mathrm{mg} / \mathrm{L}$ with an average value of $500.08 \pm 306.33 \mathrm{mg} / \mathrm{L}$. TSS for the upstream ranged from 21 to $775 \mathrm{mg} / \mathrm{L}$ with a mean concentration of $180.09 \pm 114.29 \mathrm{mg} / \mathrm{L}$ while the downstream ranged from 17 to $2780 \mathrm{mg} / \mathrm{L}$ with a mean value of $94.58 \pm$ $75.21 \mathrm{mg} / \mathrm{L}$. TS for upstream ranged from 59 to $2900 \mathrm{mg} / \mathrm{L}$ with a mean concentration of $1032.91 \pm 492.67 \mathrm{mg} / \mathrm{L}$ while the downstream ranged from 57 to $3390 \mathrm{mg} / \mathrm{L}$ with a mean concentration of $803.17 \pm 314.48 \mathrm{mg} / \mathrm{L}$. Gebreyohannes et al. (2015) also reported the same trend in similar environment. Electrical conductivity (EC) values were within permissible limits throughout the sampling periods. The upstream of the river had higher turbidity values compared to the downstream of the river. This might be due to daily disturbance of the river by different anthropogenic activities.

The Dissolved Oxygen (DO) ranged from 7.2 to $26 \mathrm{mg} / \mathrm{L}$ for the upstream with mean value of $16.34 \pm 6.37 \mathrm{mg} / \mathrm{L}$ while the downstream ranged from 0.97 to $25 \mathrm{mg} / \mathrm{L}$ with mean DO of $16.81 \pm 6.77 \mathrm{mg} / \mathrm{L}$. The DO exceeded standard values for both sampling points during the rainy season while the DO was low during the dry season. This was due to increase in temperature and presence of degradable organic matter (Uzoekwe and Oghosanine, 2011) from the depot effluents to the receiving river body. The low DO during the dry season may affect the aquatic habitats in the water and also cause an adverse effect on the villagers using the river water for consumption and domestic use. Biochemical Oxygen Demand (BOD) for the upstream ranged from 0.25 to $17 \mathrm{mg} / \mathrm{L}$ with mean concentration of $7.67 \pm$ $5.99 \mathrm{mg} / \mathrm{L}$ while the downstream ranged from 0.79 to $12.4 \mathrm{mg} / \mathrm{L}$ with an average concentration of $6.27 \pm 3.11 \mathrm{mg} / \mathrm{L}$ (Table 2). The BOD of the upstream was higher than the downstream due to high organic loads in the river water which may be attributed to the washing of locust beans (Parkiabiglobosa) into the river. Increased levels of BOD decrease the dissolved oxygen content in the river water (Ubwa et al. 2013). Hence the water is not fit for consumption and it may cause ailment to those villagers using it as a source of water. Total alkalinity (TA) for the upstream ranged 
from 24 to $366 \mathrm{mg} / \mathrm{L}$ with an average concentration $91.64 \pm 65.72 \mathrm{mg} / \mathrm{L}$ while downstream ranged from 22 to $270 \mathrm{mg} / \mathrm{L}$ with a mean concentration $66.42 \pm 43.29$. The TA was within the standard values except June 2015 and March 2016 upstream (Table not shown), which may be due to the weathering of rocks, waste discharge from the villagers' activities and microbial decomposition of organic matter in the water body during these months. Aziz and Fakhrey (2016) also reported that TA was highest in March and it exceeded permissible limits as reported in this present study. Total Hardness (TH) was within the permissible limits throughout the sampling periods.

The nitrate levels in the upstream ranged from 1.83 to $8.7 \mathrm{mg} / \mathrm{L}$ with a mean concentration of $5.36 \pm 2.43 \mathrm{mg} / \mathrm{L}$ while downstream ranged from 1.41 to $8.58 \mathrm{mg} / \mathrm{L}$ with an average concentration of $3.968 \pm 2.53 \mathrm{mg} / \mathrm{L}$. Uzoekwe and Oghosanine (2011) reported this same trend for nitrate concentration to be within permissible limits with refinery discharge been $0.87 \mathrm{mg} / \mathrm{L}$, the values obtained for upstream and downstream are $0.35 \mathrm{mg} / \mathrm{L}$ and $0.25 \mathrm{mg} / \mathrm{L}$ respectively. Phosphate concentration in the river upstream ranged from 1.06 to $18.31 \mathrm{mg} / \mathrm{L}$ with a mean of $5.48 \pm 5.13 \mathrm{mg} / \mathrm{L}$ while downstream ranged from 0.5 to $8.43 \mathrm{mg} / \mathrm{L}$ with a mean concentration of $3.238 \pm 3.00 \mathrm{mg} / \mathrm{L}$. Phosphate concentrations exceeded the permissible limits with $100 \%$ violation throughout the sampling periods except April, 2016 which had $50 \%$ violation of standards (Figure 2). Continuous entry of domestic sewage rich in phosphate additive is responsible for increase of phosphate (Sahoo et al. 2016). The upstream sulphate concentration ranged from $8.2-95.59 \mathrm{mg} / \mathrm{L}$ with mean of $43.05 \pm 33.70 \mathrm{mg} / \mathrm{L}$ while downstream ranged from 6.73 to $157.93 \mathrm{mg} / \mathrm{L}$ with a mean concentration of $50.4 \pm 50.69$ $\mathrm{mg} / \mathrm{L}$. Sulphate contents of the river were within the WHO highest permissible limits of $250 \mathrm{mg} / \mathrm{L}$. This result is in agreement with the result obtained by Muniyan and Ambedkar (2011). Chloride concentration in surface water serves as an indicator of pollution caused by industrial or domestic waste (Noortheen et al. 2016). The upstream of the river ranged from 21 to $349.98 \mathrm{mg} / \mathrm{L}$ with an average concentration of $74.71 \pm 97.06$ $\mathrm{mg} / \mathrm{L}$ while the downstream ranged from 18.99 to $167.95 \mathrm{mg} / \mathrm{L}$ with a mean concentration of $53.92 \pm 50.44 \mathrm{mg} / \mathrm{L}$. The chloride concentrations in the river were within the permissible limits except March 2016 (upstream) and this may be attributed to the high temperature, less rainfall and a load of pollutants discharged into the river.

Copper concentrations fell within permissible limits while zinc, lead and chromium were higher than standard values for both sampling points. Cadmium and nickel were above permissible limits during the dry season and within the acceptable values during the rainy season. Concentration of copper ranged from 0.015 to $0.02 \mathrm{mg} / \mathrm{L}$ in upstream with a mean 
concentration of $0.058 \pm 0.041 \mathrm{mg} / \mathrm{L}$ while downstream ranged from 0.02 to $0.17 \mathrm{mg} / \mathrm{L}$ with an average value of $0.059 \pm 0.046 \mathrm{mg} / \mathrm{L}$. A high load of $\mathrm{Cu}$ was reported earlier for similar environmental media (Etchie et al. 2011). Zinc concentration ranged from 0.13 to $1.645 \mathrm{mg} / \mathrm{L}$ with an average concentration of $0.465 \pm 0.523 \mathrm{mg} / \mathrm{L}$ in upstream of the river while downstream ranged from 0.1 to $1.645 \mathrm{mg} / \mathrm{L}$ with a mean concentration of $0.374 \pm 0.431 \mathrm{mg} / \mathrm{L}$. Zinc exceeded WHO standard of $0.01-0.05 \mathrm{mg} / \mathrm{L}$ and EPA standard of $0.05 \mathrm{mg} / \mathrm{L}$ throughout the sampling periods. Adewuyi et al. (2011) also reported that, $\mathrm{Zn}$ had the highest metal burden which exceeded the standard values for surface water around and within the vicinity of petroleum depot. Chromium concentration ranged from 0.1 to $0.836 \mathrm{mg} / \mathrm{L}$ with a mean concentration of $0.450 \pm 0.323 \mathrm{mg} / \mathrm{L}$ while the downstream of the river ranged from 0.08 to $1.303 \mathrm{mg} / \mathrm{L}$ with an average value of $0.462 \pm$ $0.381 \mathrm{mg} / \mathrm{L}$. Chromium content of the upstream was below detectable limits while that of the downstream gave values higher than permissible limits in July 2015, October 2015 and February 2016. Lead concentration for upstream of the river ranged from 0.17 to $1.021 \mathrm{mg} / \mathrm{L}$ with a mean concentration of $0.524 \pm 0.454 \mathrm{mg} / \mathrm{L}$ while downstream ranged from 0.231 to $2.38 \mathrm{mg} / \mathrm{L}$ with an average concentration of $1.158 \pm 1.105 \mathrm{mg} / \mathrm{L}$. High concentration of lead during the rainy and late dry season can be attributed to runoff from the depot effluents and automobile from the road that cut across the river (Manikandan et al. 2016). Concentration of cadmium ranged from 0.05 to $1.912 \mathrm{mg} / \mathrm{L}$ with a mean concentration of $0.521 \pm 0.927 \mathrm{mg} / \mathrm{L}$ in the upstream of the river while downstream of the river ranged from 0.01 to 27.246 with a mean value $5.472 \pm 12.172 \mathrm{mg} / \mathrm{L}$. The cadmium concentrations detected during dry season have $100 \%$ violation of the standard values. Nickel concentration was below detectable limits throughout the sampling period except October and November 2015. The downstream of the river gave a concentration of $0.191 \mathrm{mg} / \mathrm{L}$ in October 2015 while both upstream and downstream gave 0.682 and $0.556 \mathrm{mg} / \mathrm{L}$ respectively in November 2015. These concentrations were far above the maximum contamination level. The concentration of heavy metals for both upstream and downstream of the river in $\mathrm{mg} / \mathrm{L}$ was in the order of $\mathrm{Cd}>\mathrm{Zn}$ $>\mathrm{Pb}>\mathrm{Cr}>\mathrm{Ni}>\mathrm{Cu}$.

Descriptive statistical analysis parameters computed include mean, minimum, maximum, standard deviation and standard error of mean. From Table 3, the $\mathrm{pH}$, temperature and DO have minimum mean values in February, 2016, which may be attributed to the dried up of the upstream of the river where no sample was obtained that month while other physicochemical parameters such as TDS, TSS and TS in October, 2015 and BOD, EC, TH and TA in November, 2015 have minimum average values during the rainy season. Turbidity had its minimum mean value in April, 
2016. The maximum mean concentration for most parameters were obtained during the dry season and early rainy season throughout the twelve-monthly sampling period, DO had its highest mean value in October, 2015, which may be attributed to the increase in dilution, tide and flow rate of the river.

Table 4 shows that nitrate had its highest mean value during the rainy season in October, 2015 while other anions have their highest mean concentration during the dry season, March and April 2016. From Table 5, the maximum mean concentrations for copper and lead were in the month of May, 2016, chromium and nickel were in the month of November, 2015 while cadmium and zinc were in the month of February and April, 2016 respectively. It was observed that the summary of the metal analysis also showed a significant difference in the measure of dispersion and central tendency of high concentration value for dry and rainy seasons of sampling. Box plot variation of concentration of the anions and heavy metals for the sampling points across the river also showed a wide variation pattern for anions and heavy metals during the dry season while the rainy season have little or no difference in the variation pattern from the extracted mean. Therefore, it is noteworthy that the seasons of sampling have a very huge effect on the concentration of the parameters studied.

From the Pearson correlation coefficient of ions over the sampling time (Table 6). It was revealed that there was a significant correlation $(\mathrm{P}<0.01)$ among phosphate, nitrate and nickel; chloride and phosphate; zinc and sulphate; copper and lead; cadmium and chromium; indicating that the metals and anions are from a common source. This common source is supposed to be partly due to the depot wastewater, geogenic and other anthropogenic means through villager's use of the water as their main source of water resource for domestic use.

Table 2: Average values of the physicochemical parameters of water samples from June 2015 to May 2016

\begin{tabular}{cccccc}
\hline Parameters & Upstream & Downstream & $\begin{array}{c}\text { WHO } \\
\text { Standard }\end{array}$ & $\begin{array}{c}\text { SON } \\
\text { Standard }\end{array}$ & $\begin{array}{c}\text { EPA } \\
\text { Standard }\end{array}$ \\
\hline $\mathrm{pH}$ & $\begin{array}{c}6.40 \pm 1.17 \\
(4.2-7.8)\end{array}$ & $\begin{array}{c}7.05 \pm 0.79 \\
(5.1-8.5)\end{array}$ & $6.5-7.5$ & $6.5-8.5$ & $6.5-8.5$ \\
\hline Temp. $\left({ }^{\circ} \mathrm{C}\right)$ & $\begin{array}{c}29.45 \pm 3.98 \\
(24.5-37)\end{array}$ & $\begin{array}{c}29.79 \pm 3.61 \\
(24.5-37)\end{array}$ & 25 & Ambient & $\mathrm{NS}$ \\
\hline DO $(\mathrm{mg} / \mathrm{L})$ & $\begin{array}{c}16.34 \pm 6.37 \\
(7.2-26)\end{array}$ & $\begin{array}{c}16.81 \pm 6.77 \\
(0.97-25)\end{array}$ & 15 & $\mathrm{NS}$ & $\mathrm{NS}$ \\
\hline BOD $(\mathrm{mg} / \mathrm{L})$ & $\begin{array}{c}7.67 \pm 5.99 \\
(0.25-17)\end{array}$ & $\begin{array}{c}6.27 \pm 3.11 \\
(0.79-12.4)\end{array}$ & 10 & $\mathrm{NS}$ & $\mathrm{NS}$ \\
\hline $\mathrm{TDS}(\mathrm{mg} / \mathrm{L})$ & $\begin{array}{c}508.02 \pm 409.16 \\
(38-2125)\end{array}$ & $\begin{array}{c}500.08 \pm 306.33 \\
(40-1300)\end{array}$ & 1000 & 500 & \multirow{2}{*}{500} \\
\hline TSS $(\mathrm{mg} / \mathrm{L})$ & $\begin{array}{c}180.09 \pm 114.29 \\
(21-775)\end{array}$ & $\begin{array}{c}94.58 \pm 75.21 \\
(17-2780)\end{array}$ & 80 & $\mathrm{NS}$ & $\mathrm{NS}$ \\
\hline
\end{tabular}




\begin{tabular}{|c|c|c|c|c|c|}
\hline $\mathrm{TS}(\mathrm{mg} / \mathrm{L})$ & $\begin{array}{c}1032.91 \pm \\
492.67 \\
(59-2900)\end{array}$ & $\begin{array}{c}803.17 \pm 314.48 \\
(57-3390)\end{array}$ & 1500 & 1500 & NS \\
\hline $\mathrm{EC}(\mu \mathrm{S} / \mathrm{cm})$ & $\begin{array}{c}193.43 \pm 218.75 \\
(37-666)\end{array}$ & $\begin{array}{c}150.13 \pm 103.31 \\
(50.7-362) \\
\end{array}$ & 1500 & 1000 & $4.7-5.8$ \\
\hline $\begin{array}{l}\text { Turbidity } \\
\text { (NTU) }\end{array}$ & $\begin{array}{c}177.18 \pm 126.09 \\
(19-1048)\end{array}$ & $\begin{array}{c}65.35 \pm 49.43 \\
(6-174)\end{array}$ & 5 & 5 & $5-25$ \\
\hline TH (mg/L) & $\begin{array}{c}76.55 \pm 57.15 \\
(22-192)\end{array}$ & $\begin{array}{c}74.25 \pm 45.98 \\
(18-140)\end{array}$ & 500 & 150 & NS \\
\hline TA (mg/L) & $\begin{array}{c}91.64 \pm 65.72 \\
(24-366) \\
\end{array}$ & $\begin{array}{c}66.42 \pm 43.29 \\
(22-270) \\
\end{array}$ & 200 & NS & NS \\
\hline $\mathrm{NO}_{3}{ }^{-}(\mathrm{mg} / \mathrm{L})$ & $\begin{array}{l}5.36 \pm 2.43 \\
(1.83-8.7) \\
\end{array}$ & $\begin{array}{l}3.968 \pm 2.53 \\
(1.41-8.58) \\
\end{array}$ & 10 & 10 & 10 \\
\hline $\mathrm{PO}_{4}{ }^{3-}(\mathrm{mg} / \mathrm{L})$ & $\begin{array}{c}5.48 \pm 5.13 \\
(1.06-18.31) \\
\end{array}$ & $\begin{array}{c}3.238 \pm 3.00 \\
(0.5-8.43)\end{array}$ & 0.5 & $\begin{array}{c}0.01- \\
0.03\end{array}$ & NS \\
\hline $\mathrm{SO}_{4}{ }^{2-}(\mathrm{mg} / \mathrm{L})$ & $\begin{array}{c}43.05 \pm 33.70 \\
(8.2-95.53)\end{array}$ & $\begin{array}{c}50.40 \pm 50.69 \\
(6.73-157.93) \\
\end{array}$ & 200 & 100 & 250 \\
\hline $\mathrm{Cl}^{-}(\mathrm{mg} / \mathrm{L})$ & $\begin{array}{l}74.71 \pm 97.06 \\
(21-349.98)\end{array}$ & $\begin{array}{c}53.92 \pm 50.44 \\
(18.99-167.95)\end{array}$ & 250 & 250 & 250 \\
\hline $\mathrm{Cu}(\mathrm{mg} / \mathrm{L})$ & $\begin{array}{l}0.058 \pm 0.041 \\
(0.015-0.02)\end{array}$ & $\begin{array}{c}0.059 \pm 0.046 \\
(0.02-0.17) \\
\end{array}$ & 0.5 & 1 & 1.3 \\
\hline $\mathrm{Pb}(\mathrm{mg} / \mathrm{L})$ & $\begin{array}{l}0.524 \pm 0.454 \\
(0.17-1.021)\end{array}$ & $\begin{array}{l}1.158 \pm 1.105 \\
(0.231-2.38)\end{array}$ & 0.01 & 0.01 & 0.015 \\
\hline $\mathrm{Zn}(\mathrm{mg} / \mathrm{L})$ & $\begin{array}{l}0.465 \pm 0.523 \\
(0.13-1.645)\end{array}$ & $\begin{array}{c}0.374 \pm 0.431 \\
(0.1-1.645)\end{array}$ & $0.01-0.05$ & 3 & 0.05 \\
\hline $\mathrm{Cd}(\mathrm{mg} / \mathrm{L})$ & $\begin{array}{l}0.521 \pm 0.927 \\
(0.05-1.912)\end{array}$ & $\begin{array}{l}5.472 \pm 12.172 \\
(0.01-27.246) \\
\end{array}$ & 0.003 & 0.003 & 0.005 \\
\hline $\mathrm{Cr}(\mathrm{mg} / \mathrm{L})$ & $\begin{array}{l}0.45 \pm 0.323 \\
(0.1-0.836) \\
\end{array}$ & $\begin{array}{l}0.462 \pm 0.381 \\
(0.08-1.303) \\
\end{array}$ & 0.05 & 0.05 & 0.1 \\
\hline $\mathrm{Ni}(\mathrm{mg} / \mathrm{L})$ & 0.682 & $\begin{array}{c}0.374 \pm 0.258 \\
(0.191-0.556) \\
\end{array}$ & 0.07 & 0.02 & 0.1 \\
\hline
\end{tabular}

NS: Not Stated
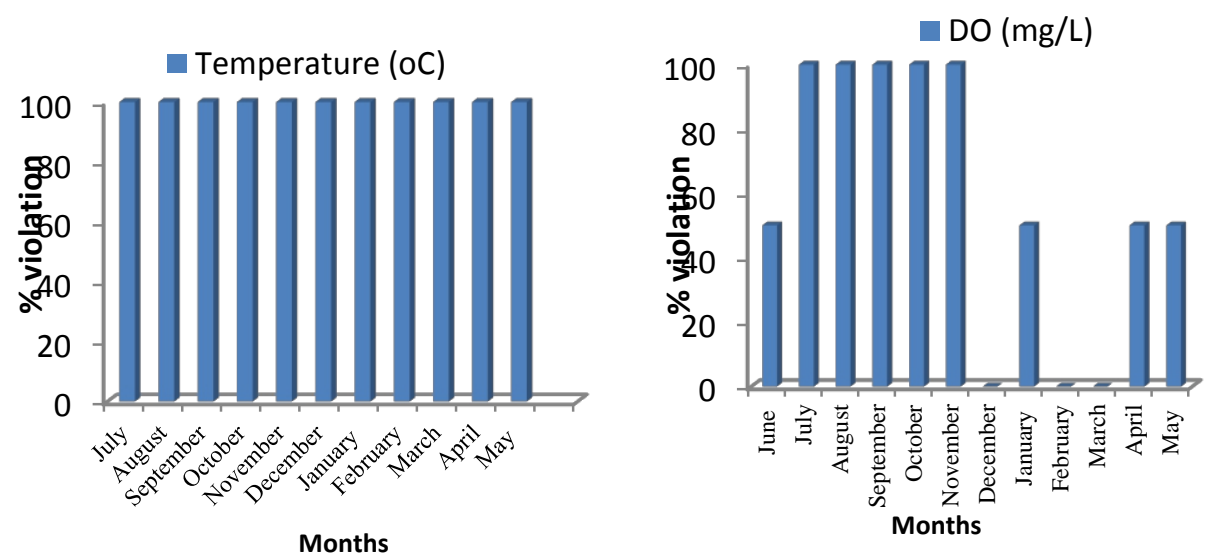

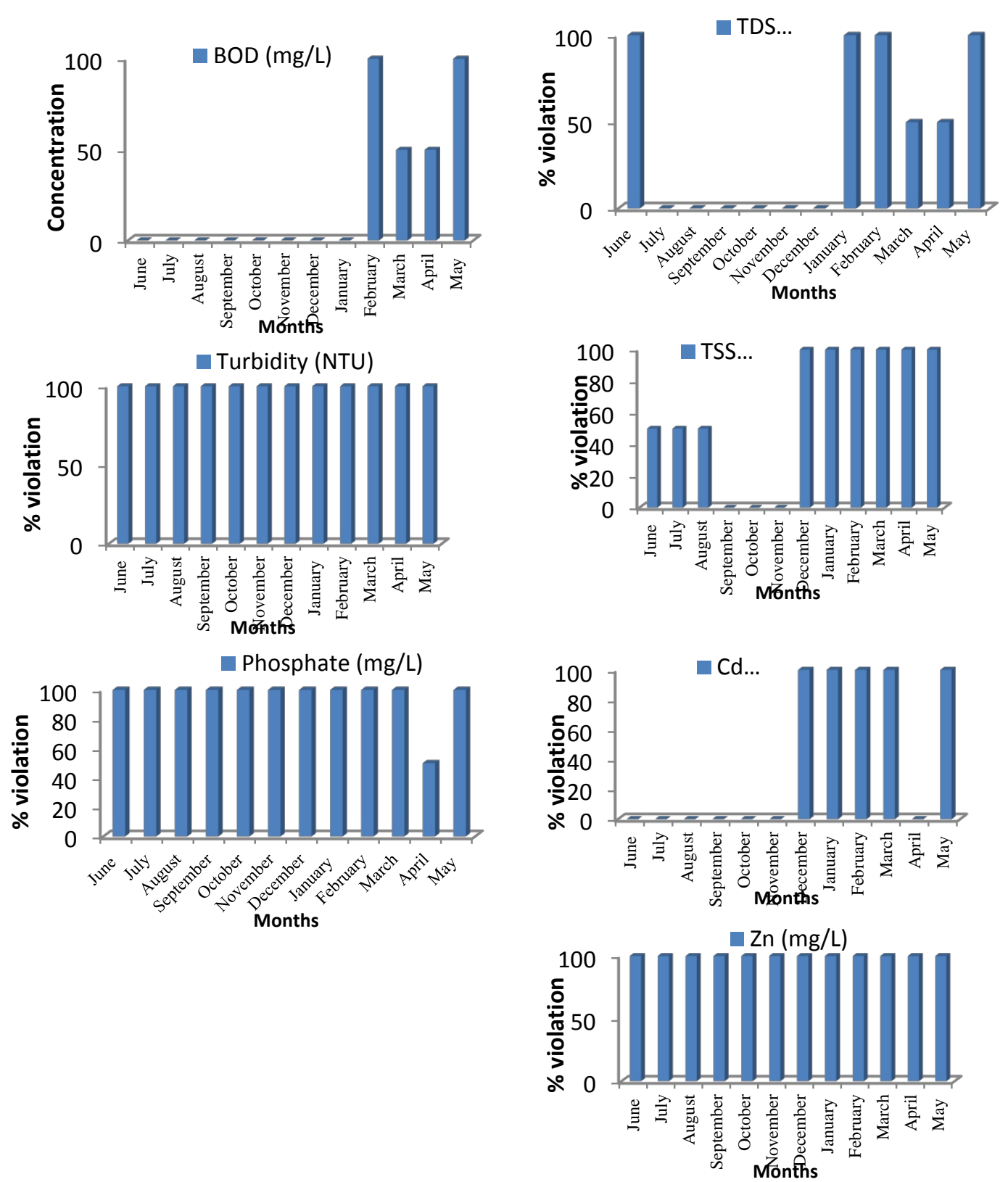

Figure 2: Graphs of summary of the percentage violation of the guideline values of water sample monitoring from June, 2015 to May, 2016 
Table 3: Summary of physicochemical parameters for the months of June 2015 to May 2016

\begin{tabular}{|c|c|c|c|c|c|c|c|c|c|c|c|c|}
\hline & Months & pH & Temperature & DO & BOD & TDS & TSS & TS & EC & Turbidity & TH & TA \\
\hline \multirow{5}{*}{ Jun-15 } & Mean & 4.95 & 36 & 15.6 & 6.905 & 1545 & 85 & 1630 & 426 & 117.7 & 164 & 318 \\
\hline & Minimum & 4.8 & 35 & 13.2 & 6.44 & 980 & 60 & 1040 & 362 & 61.4 & 136 & 270 \\
\hline & Maximum & 5.1 & 37 & 18 & 7.37 & 2110 & 110 & 2220 & 490 & 174 & 192 & 366 \\
\hline & Std. Deviation & 0.21213 & 1.41421 & 3.39411 & 0.65761 & 799.0307 & 35.35534 & 834.386 & 90.50967 & 79.62022 & 39.59798 & 67.88225 \\
\hline & $\begin{array}{c}\text { Std. Error of } \\
\text { Mean }\end{array}$ & 0.15 & 1 & 2.4 & 0.465 & 565 & 25 & 590 & 64 & 56.3 & 28 & 48 \\
\hline \multirow{4}{*}{ Jul-15 } & Mean & 6.8 & 29.75 & 16.7 & 5.97 & 340 & 56 & 396 & 215.5 & 45 & 102 & 60 \\
\hline & Minimum & 6.7 & 29.5 & 14.2 & 5.76 & 270 & 22 & 360 & 161 & 12 & 96 & 42 \\
\hline & Maximum & 6.9 & 30 & 19.2 & 6.18 & 410 & 90 & 432 & 270 & 78 & 108 & 78 \\
\hline & $\begin{array}{c}\text { Std. Error of } \\
\text { Mean }\end{array}$ & 0.1 & 0.25 & 2.5 & 0.21 & 70 & 34 & 36 & 54.5 & 33 & 6 & 18 \\
\hline \multirow{5}{*}{ Aug-15 } & Mean & 6.85 & 28.25 & 18.3 & 5.82 & 170 & 65 & 235 & 51.05 & 154 & 67.5 & 67.5 \\
\hline & Minimum & 6.7 & 28 & 16.6 & 4.19 & 90 & 40 & 180 & 48.8 & 151 & 61 & 63 \\
\hline & Maximum & 7 & 28.5 & 20 & 7.45 & 250 & 90 & 290 & 53.3 & 157 & 74 & 72 \\
\hline & Std. Deviation & 0.21213 & 0.35355 & 2.40416 & 2.30517 & 113.1371 & 35.35534 & 77.78175 & 3.18198 & 4.24264 & 9.19239 & 6.36396 \\
\hline & $\begin{array}{c}\text { Std. Error of } \\
\text { Mean }\end{array}$ & 0.15 & 0.25 & 1.7 & 1.63 & 80 & 25 & 55 & 2.25 & 3 & 6.5 & 4.5 \\
\hline \multirow{4}{*}{ Sep-15 } & Mean & 7.2 & 26.25 & 20.25 & 5.17 & 175 & 35 & 210 & 59.75 & 96 & 41 & 50 \\
\hline & Maximum & 7.3 & 27.5 & 23.3 & 6.44 & 280 & 40 & 310 & 62.6 & 97 & 42 & 62 \\
\hline & Std. Deviation & 0.14142 & 1.76777 & 4.31335 & 1.79605 & 148.4924 & 7.07107 & 141.4214 & 4.03051 & 1.41421 & 1.41421 & 16.97056 \\
\hline & $\begin{array}{l}\text { Std. Error of } \\
\text { Mean }\end{array}$ & 0.1 & 1.25 & 3.05 & 1.27 & 105 & 5 & 100 & 2.85 & 1 & 1 & 12 \\
\hline \multirow{5}{*}{ Oct-15 } & Mean & 6.85 & 24.75 & 24.7 & 2.735 & 39 & 19 & 58 & 50.15 & 52.5 & 32 & 25 \\
\hline & Minimum & 6.8 & 24.5 & 23.4 & 0.25 & 38 & 17 & 57 & 46.9 & 52 & 26 & 24 \\
\hline & Maximum & 6.9 & 25 & 26 & 5.22 & 40 & 21 & 59 & 53.4 & 53 & 38 & 26 \\
\hline & Std. Deviation & 0.07071 & 0.35355 & 1.83848 & 3.51432 & 1.41421 & 2.82843 & 1.41421 & 4.59619 & 0.70711 & 8.48528 & 1.41421 \\
\hline & $\begin{array}{c}\text { Std. Error of } \\
\text { Mean }\end{array}$ & 0.05 & 0.25 & 1.3 & 2.485 & 1 & 2 & 1 & 3.25 & 0.5 & 6 & - \\
\hline \multirow{5}{*}{ Nov-15 } & Mean & 7.45 & 24.75 & 21.05 & 1.455 & 195 & 51 & 246 & 45.3 & 59 & 20 & 24 \\
\hline & Minimum & 7.1 & 24.5 & 17.3 & 0.79 & 190 & 50 & 242 & 39.9 & 58 & 18 & 22 \\
\hline & Maximum & 7.8 & 25 & 24.8 & 2.12 & 200 & 52 & 250 & 50.7 & 60 & 22 & 26 \\
\hline & Std. Deviation & 0.49497 & 0.35355 & 5.3033 & 0.94045 & 7.07107 & 1.41421 & 5.65685 & 7.63675 & 1.41421 & 2.82843 & 2.82843 \\
\hline & $\begin{array}{c}\text { Std. Error of } \\
\text { Mean }\end{array}$ & 0.35 & 0.25 & 3.75 & 0.665 & 5 & 1 & 4 & 5.4 & 1 & 2 & 2 \\
\hline
\end{tabular}




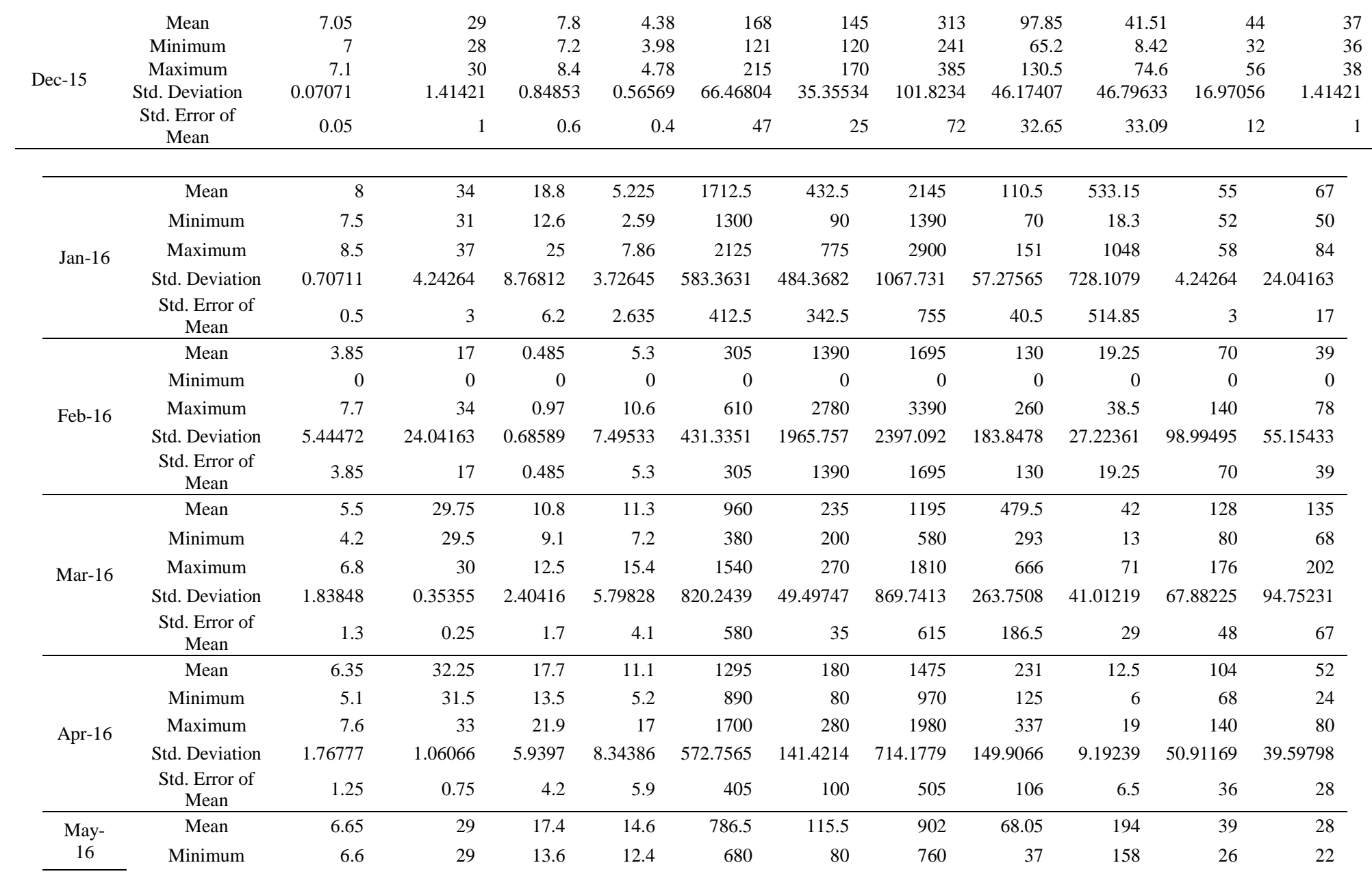




\begin{tabular}{|c|c|c|c|c|c|c|c|c|c|c|c|c|}
\hline & Maximum & 6.7 & 29 & 21.2 & 16.8 & 893 & 151 & 1044 & 99.1 & 230 & 52 & 34 \\
\hline & Std. Deviation & 0.07071 & 0 & 5.37401 & 3.11127 & 150.6137 & 50.20458 & 200.8183 & 43.91133 & 50.91169 & 18.38478 & 8.48528 \\
\hline & $\begin{array}{l}\text { Std. Error of } \\
\text { Mean }\end{array}$ & 0.05 & 0 & 3.8 & 2.2 & 106.5 & 35.5 & 142 & 31.05 & 36 & 13 & 6 \\
\hline \multirow{5}{*}{ Total } & Mean & 6.4583 & 28.3958 & 15.7987 & 7.0119 & 640.9167 & 234.0833 & 875 & 163.7208 & 113.8842 & 72.2083 & 75.2083 \\
\hline & Minimum & 0 & 0 & 0 & 0 & 0 & 0 & 0 & 0 & 0 & 0 & 0 \\
\hline & Maximum & 8.5 & 37 & 26 & 17 & 2125 & 2780 & 3390 & 666 & 1048 & 192 & 366 \\
\hline & Std. Deviation & 1.70036 & 7.05257 & 7.14054 & 5.81001 & 663.4726 & 564.7109 & 943.7566 & 166.109 & 208.1589 & 51.66782 & 85.52395 \\
\hline & $\begin{array}{l}\text { Std. Error of } \\
\text { Mean }\end{array}$ & 0.34708 & 1.4396 & 1.45756 & 1.4525 & 135.4308 & 115.2711 & 192.6435 & 33.90685 & 42.49025 & 10.54665 & 17.4575 \\
\hline
\end{tabular}

Table 4: Summary of anions for the months of June, 2015 to May, 2016

\begin{tabular}{|c|c|c|c|c|c|}
\hline & Months & $\mathrm{NO}_{3}{ }^{2-}(\mathrm{mg} / \mathrm{L})$ & $\mathrm{PO}_{4}{ }^{3-}(\mathrm{mg} / \mathrm{L})$ & $\mathrm{SO}_{4}{ }^{2-}(\mathrm{mg} / \mathrm{L})$ & $\mathrm{Cl}^{-}(\mathrm{mg} / \mathrm{L})$ \\
\hline \multirow{8}{*}{ Jun., 2015} & Mean & 3.72 & 5.58 & 97 & 145.955 \\
\hline & Minimum & 1.83 & 2.73 & 92 & 123.96 \\
\hline & Maximum & 5.61 & 8.43 & 102 & 167.95 \\
\hline & Std. Deviation & 2.67286 & 4.03051 & 7.07107 & 31.10563 \\
\hline & Std. Error of Mean & 1.89 & 2.85 & 5 & 21.995 \\
\hline & $\begin{array}{l}\text { WHO maximum } \\
\text { permissible limit }\end{array}$ & 10 & 0.5 & 200 & 250 \\
\hline & $\begin{array}{c}\text { SON maximum } \\
\text { permissible limit }\end{array}$ & 10 & 0.03 & 100 & 250 \\
\hline & $\begin{array}{l}\text { EPA maximum } \\
\text { permissible limit }\end{array}$ & 10 & NS & 250 & 250 \\
\hline \multirow{3}{*}{ Jul., 2015} & Mean & 2.11 & 2.815 & 56 & 96.97 \\
\hline & Minimum & 1.73 & 2.49 & 27 & 58.98 \\
\hline & Maximum & 2.49 & 3.14 & 85 & 134.96 \\
\hline
\end{tabular}




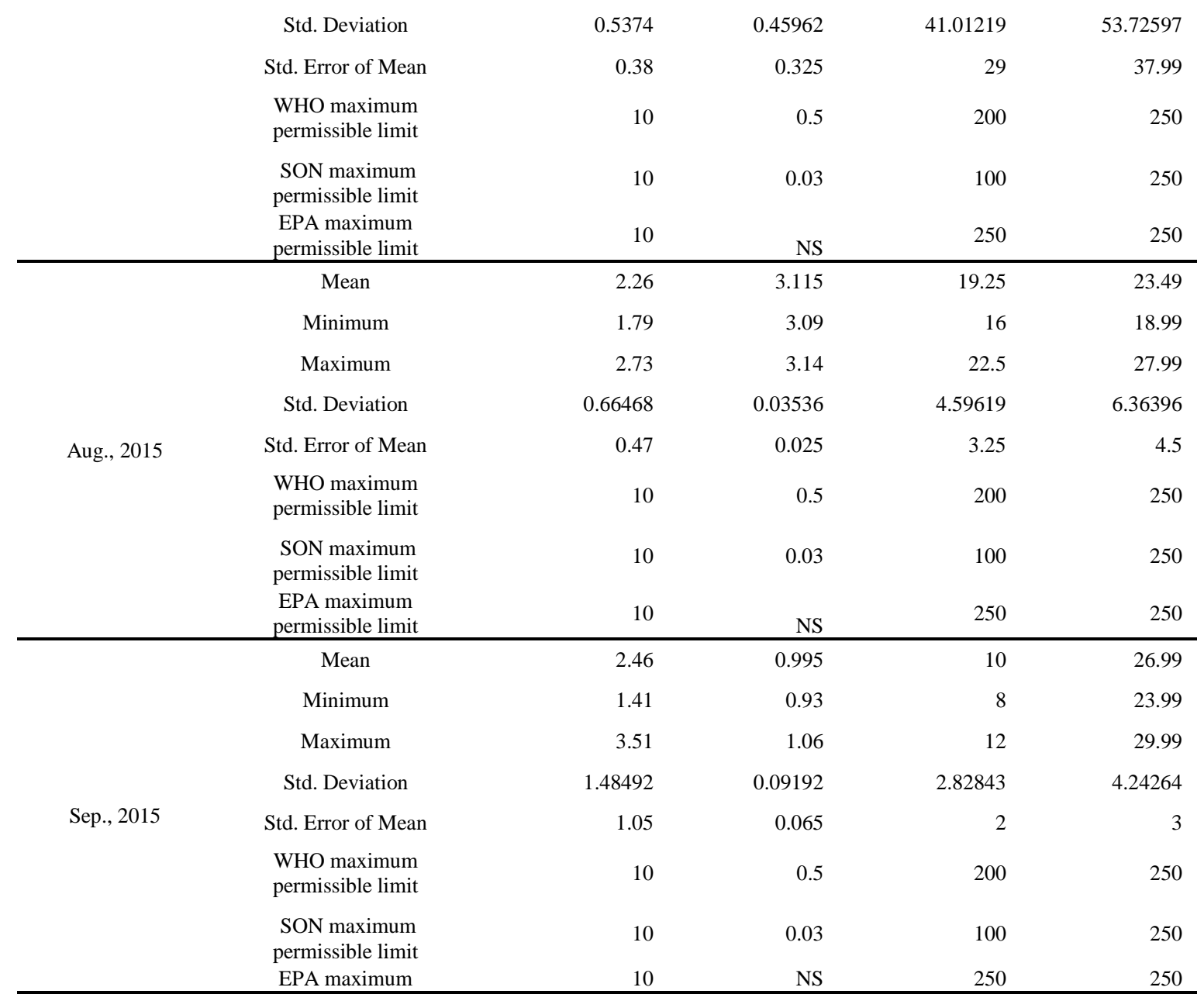




\begin{tabular}{|c|c|c|c|c|c|}
\hline \multirow{8}{*}{ Oct., 2015} & Mean & 6.865 & 7.88 & 9.33 & 20.99 \\
\hline & Minimum & 5.51 & 7.69 & 8.73 & 18.99 \\
\hline & Maximum & 8.22 & 8.07 & 9.93 & 22.99 \\
\hline & Std. Deviation & 1.91626 & 0.2687 & 0.84853 & 2.82843 \\
\hline & Std. Error of Mean & 1.355 & 0.19 & 0.6 & 2 \\
\hline & $\begin{array}{l}\text { WHO maximum } \\
\text { permissible limit }\end{array}$ & 10 & 0.5 & 200 & 250 \\
\hline & $\begin{array}{l}\text { SON maximum } \\
\text { permissible limit }\end{array}$ & 10 & 0.03 & 100 & 250 \\
\hline & $\begin{array}{l}\text { EPA maximum } \\
\text { permissible limit }\end{array}$ & 10 & NS & 250 & 250 \\
\hline \multirow{8}{*}{ Nov., 2015} & Mean & 8.64 & 7.785 & 7.465 & 40.99 \\
\hline & Minimum & 8.58 & 7.56 & 6.73 & 33.99 \\
\hline & Maximum & 8.7 & 8.01 & 8.2 & 47.99 \\
\hline & Std. Deviation & 0.08485 & 0.3182 & 1.03945 & 9.89949 \\
\hline & Std. Error of Mean & 0.06 & 0.225 & 0.735 & 7 \\
\hline & $\begin{array}{l}\text { WHO maximum } \\
\text { permissible limit }\end{array}$ & 10 & 0.5 & 200 & 250 \\
\hline & $\begin{array}{c}\text { SON maximum } \\
\text { permissible limit }\end{array}$ & 10 & 0.03 & 100 & 250 \\
\hline & $\begin{array}{l}\text { EPA maximum } \\
\text { permissible limit }\end{array}$ & 10 & NS & 250 & 250 \\
\hline \multirow{5}{*}{ Dec., 2015} & Mean & 5.7 & 1.385 & 57.365 & 20.5 \\
\hline & Minimum & 5.44 & 1.11 & 56.73 & 20 \\
\hline & Maximum & 5.96 & 1.66 & 58 & 21 \\
\hline & Std. Deviation & 0.3677 & 0.38891 & 0.89803 & 0.70711 \\
\hline & Std. Error of Mean & 0.26 & 0.275 & 0.635 & 0.5 \\
\hline
\end{tabular}




\begin{tabular}{|c|c|c|c|c|c|}
\hline & $\begin{array}{l}\text { WHO maximum } \\
\text { permissible limit }\end{array}$ & 10 & 0.5 & 200 & 250 \\
\hline & $\begin{array}{c}\text { SON maximum } \\
\text { permissible limit }\end{array}$ & 10 & 0.03 & 100 & 250 \\
\hline & $\begin{array}{l}\text { EPA maximum } \\
\text { permissible limit }\end{array}$ & 10 & NS & 250 & 250 \\
\hline \multirow{8}{*}{ Jan., 2016} & Mean & 5.225 & 5.41 & 43.665 & 22.5 \\
\hline & Minimum & 3.05 & 1.29 & 29.33 & 21 \\
\hline & Maximum & 7.4 & 9.53 & 58 & 24 \\
\hline & Std. Deviation & 3.07591 & 5.82656 & 20.27275 & 2.12132 \\
\hline & Std. Error of Mean & 2.175 & 4.12 & 14.335 & 1.5 \\
\hline & $\begin{array}{l}\text { WHO maximum } \\
\text { permissible limit }\end{array}$ & 10 & 0.5 & 200 & 250 \\
\hline & $\begin{array}{l}\text { SON maximum } \\
\text { permissible limit }\end{array}$ & 10 & 0.03 & 100 & 250 \\
\hline & $\begin{array}{l}\text { EPA maximum } \\
\text { permissible limit }\end{array}$ & 10 & NS & 250 & 250 \\
\hline \multirow{8}{*}{ Feb., 2016} & Mean & 1.305 & 0.355 & 53.065 & 30.49 \\
\hline & Minimum & 0 & 0 & 0 & 0 \\
\hline & Maximum & 2.61 & 0.71 & 106.13 & 60.98 \\
\hline & Std. Deviation & 1.84555 & 0.50205 & 75.04524 & 43.11937 \\
\hline & Std. Error of Mean & 1.305 & 0.355 & 53.065 & 30.49 \\
\hline & $\begin{array}{l}\text { WHO maximum } \\
\text { permissible limit }\end{array}$ & 10 & 0.5 & 200 & 250 \\
\hline & $\begin{array}{l}\text { SON maximum } \\
\text { permissible limit }\end{array}$ & 10 & 0.03 & 100 & 250 \\
\hline & $\begin{array}{l}\text { EPA maximum } \\
\text { permissible limit }\end{array}$ & 10 & NS & 250 & 250 \\
\hline Mar., 2016 & Mean & 4.88 & 10.56 & 45.265 & 193.45 \\
\hline
\end{tabular}




\begin{tabular}{|c|c|c|c|c|c|}
\hline & Minimum & 1.87 & 2.81 & 15.4 & 37 \\
\hline & Maximum & 7.89 & 18.31 & 75.13 & 349.9 \\
\hline & Std. Deviation & 4.25678 & 10.96016 & 42.23549 & 221.25371 \\
\hline & Std. Error of Mean & 3.01 & 7.75 & 29.865 & 156.45 \\
\hline & $\begin{array}{l}\text { WHO maximum } \\
\text { permissible limit }\end{array}$ & 10 & 0.5 & 200 & 250 \\
\hline & $\begin{array}{l}\text { SON maximum } \\
\text { permissible limit }\end{array}$ & 10 & 0.03 & 100 & 250 \\
\hline & $\begin{array}{l}\text { EPA maximum } \\
\text { permissible limit }\end{array}$ & 10 & NS & 250 & 250 \\
\hline \multirow{8}{*}{ Apr., 2016} & Mean & 4.78 & 1.84 & 126.73 & 23.59 \\
\hline & Minimum & 4.46 & 0.5 & 95.53 & 19.19 \\
\hline & Maximum & 5.1 & 3.18 & 157.93 & 27.99 \\
\hline & Std. Deviation & 0.45255 & 1.89505 & 44.12346 & 6.22254 \\
\hline & Std. Error of Mean & 0.32 & 1.34 & 31.2 & 4.4 \\
\hline & $\begin{array}{l}\text { WHO maximum } \\
\text { permissible limit }\end{array}$ & 10 & 0.5 & 200 & 250 \\
\hline & $\begin{array}{l}\text { SON maximum } \\
\text { permissible limit }\end{array}$ & 10 & 0.03 & 100 & 250 \\
\hline & $\begin{array}{l}\text { EPA maximum } \\
\text { permissible limit }\end{array}$ & 10 & NS & 250 & 250 \\
\hline \multirow{6}{*}{ May, 2016} & Mean & 6.825 & 2.245 & 14.07 & 88.07 \\
\hline & Minimum & 5.85 & 2.05 & 12.87 & 86.17 \\
\hline & Maximum & 7.8 & 2.44 & 15.27 & 89.97 \\
\hline & Std. Deviation & 1.37886 & 0.27577 & 1.69706 & 2.68701 \\
\hline & Std. Error of Mean & 0.975 & 0.195 & 1.2 & 1.9 \\
\hline & $\begin{array}{l}\text { WHO maximum } \\
\text { permissible limit }\end{array}$ & 10 & 0.5 & 200 & 250 \\
\hline
\end{tabular}




\begin{tabular}{rcrrrr} 
& $\begin{array}{c}\text { SON maximum } \\
\text { permissible limit } \\
\text { EPA maximum } \\
\text { permissible limit }\end{array}$ & 10 & 0.03 & 100 & 250 \\
\hline \multirow{4}{*}{ Total } & Mean & 10 & NS & 250 & 250 \\
& Minimum & 4.5642 & 4.1638 & 44.9337 & 61.1654 \\
& Maximum & 0 & 0 & 0 & 0 \\
& Std. Deviation & 8.7 & 18.31 & 157.93 & 349.9 \\
& Std. Error of Mean & 2.62892 & 4.20203 & 42.75363 & 74.74326 \\
& 0.53663 & 0.85774 & 8.72705 & 15.2569 \\
\hline
\end{tabular}

Table 5: Summary of heavy metals for the months of June, 2015 to May, 2016

\begin{tabular}{|c|c|c|c|c|c|c|c|}
\hline & Months & $\mathrm{Cu}(\mathrm{mg} / \mathrm{l})$ & Pb (mg/l) & Zn (mg/l) & $\mathrm{Cd}(\mathrm{mg} / \mathrm{l})$ & $\operatorname{Cr}(m g / l)$ & Ni (mg/l) \\
\hline \multirow{8}{*}{ Jun., 2015} & Mean & 0.098 & 0 & 0.3555 & 0 & 0.04 & 0 \\
\hline & Minimum & 0.098 & 0 & 0.139 & 0 & 0 & 0 \\
\hline & Maximum & 0.098 & 0 & 0.572 & 0 & 0.08 & 0 \\
\hline & Std. Deviation & 0 & 0 & 0.306177 & 0 & 0.056569 & 0 \\
\hline & Std. Error of Mean & 0 & 0 & 0.2165 & 0 & 0.04 & 0 \\
\hline & $\begin{array}{l}\text { WHO maximum } \\
\text { permissible limit }\end{array}$ & 0.5 & 0.01 & 0.05 & 0.003 & 0.05 & 0.07 \\
\hline & $\begin{array}{c}\text { SON maximum } \\
\text { permissible limit }\end{array}$ & 1 & 0.01 & 3 & 0.003 & 0.05 & 0.02 \\
\hline & $\begin{array}{l}\text { EPA maximum } \\
\text { permissible limit }\end{array}$ & 1.3 & 0.015 & 0.05 & 0.005 & 0.1 & 0.1 \\
\hline \multirow{4}{*}{ Jul., 2015} & Mean & 0.039 & 0 & 0.167 & 0 & 0.435 & 0 \\
\hline & Minimum & 0.039 & 0 & 0.153 & 0 & 0.35 & 0 \\
\hline & Maximum & 0.039 & 0 & 0.181 & 0 & 0.52 & 0 \\
\hline & Std. Deviation & 0 & 0 & 0.019799 & 0 & 0.120208 & 0 \\
\hline
\end{tabular}




\begin{tabular}{|c|c|c|c|c|c|c|c|}
\hline & Std. Error of Mean & 0 & 0 & 0.014 & 0 & 0.085 & 0 \\
\hline & $\begin{array}{l}\text { WHO maximum } \\
\text { permissible limit }\end{array}$ & 0.5 & 0.01 & 0.05 & 0.003 & 0.05 & 0.07 \\
\hline & $\begin{array}{l}\text { SON maximum } \\
\text { permissible limit }\end{array}$ & 1 & 0.01 & 3 & 0.003 & 0.05 & 0.02 \\
\hline & $\begin{array}{l}\text { EPA maximum } \\
\text { permissible limit }\end{array}$ & 1.3 & 0.015 & 0.05 & 0.005 & 0.1 & 0.1 \\
\hline \multirow{8}{*}{ Aug., 2015} & Mean & 0.128 & 1.076 & 1.069 & 0 & 0.5265 & 0 \\
\hline & Minimum & 0.119 & 0.985 & 0.978 & 0 & 0.311 & 0 \\
\hline & Maximum & 0.137 & 1.167 & 1.16 & 0 & 0.742 & 0 \\
\hline & Std. Deviation & 0.012728 & 0.128693 & 0.128693 & 0 & 0.304763 & 0 \\
\hline & Std. Error of Mean & 0.009 & 0.091 & 0.091 & 0 & 0.2155 & 0 \\
\hline & $\begin{array}{l}\text { WHO maximum } \\
\text { permissible limit }\end{array}$ & 0.5 & 0.01 & 0.05 & 0.003 & 0.05 & 0.07 \\
\hline & $\begin{array}{l}\text { SON maximum } \\
\text { permissible limit }\end{array}$ & 1 & 0.01 & 3 & 0.003 & 0.05 & 0.02 \\
\hline & $\begin{array}{l}\text { EPA maximum } \\
\text { permissible limit }\end{array}$ & 1.3 & 0.015 & 0.05 & 0.005 & 0.1 & 0.1 \\
\hline \multirow{7}{*}{ Sep., 2015} & Mean & 0.1395 & 0.229 & 0.286 & 0 & 0.289 & 0 \\
\hline & Minimum & 0.121 & 0.194 & 0.276 & 0 & 0.223 & 0 \\
\hline & Maximum & 0.158 & 0.264 & 0.296 & 0 & 0.355 & 0 \\
\hline & Std. Deviation & 0.026163 & 0.049497 & 0.014142 & 0 & 0.093338 & 0 \\
\hline & Std. Error of Mean & 0.0185 & 0.035 & 0.01 & 0 & 0.066 & 0 \\
\hline & $\begin{array}{l}\text { WHO maximum } \\
\text { permissible limit }\end{array}$ & 0.5 & 0.01 & 0.05 & 0.003 & 0.05 & 0.07 \\
\hline & $\begin{array}{c}\text { SON maximum } \\
\text { permissible limit }\end{array}$ & 1 & 0.01 & 3 & 0.003 & 0.05 & 0.02 \\
\hline
\end{tabular}




\begin{tabular}{|c|c|c|c|c|c|c|c|}
\hline & $\begin{array}{l}\text { EPA maximum } \\
\text { permissible limit }\end{array}$ & 1.3 & 0.015 & 0.05 & 0.005 & 0.1 & 0.1 \\
\hline \multirow{8}{*}{ Oct., 2015} & Mean & 0.0715 & 0.103 & 0.3205 & 0 & 0.06 & 0.7705 \\
\hline & Minimum & 0.063 & 0 & 0.259 & 0 & 0 & 0 \\
\hline & Maximum & 0.08 & 0.206 & 0.382 & 0 & 0.12 & 1.541 \\
\hline & Std. Deviation & 0.012021 & 0.145664 & 0.086974 & 0 & 0.084853 & 1.089652 \\
\hline & Std. Error of Mean & 0.0085 & 0.103 & 0.0615 & 0 & 0.06 & 0.7705 \\
\hline & $\begin{array}{l}\text { WHO maximum } \\
\text { permissible limit }\end{array}$ & 0.5 & 0.01 & 0.05 & 0.003 & 0.05 & 0.07 \\
\hline & $\begin{array}{c}\text { SON maximum } \\
\text { permissible limit }\end{array}$ & 1 & 0.01 & 3 & 0.003 & 0.05 & 0.02 \\
\hline & $\begin{array}{l}\text { EPA maximum } \\
\text { permissible limit }\end{array}$ & 1.3 & 0.015 & 0.05 & 0.005 & 0.1 & 0.1 \\
\hline \multirow{8}{*}{ Nov., 2015} & Mean & 0.0785 & 0 & 0.247 & 0 & 0.6505 & 1.7535 \\
\hline & Minimum & 0.059 & 0 & 0.212 & 0 & 0.465 & 1.575 \\
\hline & Maximum & 0.098 & 0 & 0.282 & 0 & 0.836 & 1.932 \\
\hline & Std. Deviation & 0.027577 & 0 & 0.049497 & 0 & 0.262337 & 0.252437 \\
\hline & Std. Error of Mean & 0.0195 & 0 & 0.035 & 0 & 0.1855 & 0.1785 \\
\hline & $\begin{array}{l}\text { WHO maximum } \\
\text { permissible limit }\end{array}$ & 0.5 & 0.01 & 0.05 & 0.003 & 0.05 & 0.07 \\
\hline & $\begin{array}{c}\text { SON maximum } \\
\text { permissible limit }\end{array}$ & 1 & 0.01 & 3 & 0.003 & 0.05 & 0.02 \\
\hline & $\begin{array}{l}\text { EPA maximum } \\
\text { permissible limit }\end{array}$ & 1.3 & 0.015 & 0.05 & 0.005 & 0.1 & 0.1 \\
\hline \multirow{3}{*}{ Dec., 2015} & Mean & 0.0585 & 0 & 0.246 & 0.0415 & 0 & 0 \\
\hline & Minimum & 0 & 0 & 0.238 & 0.022 & 0 & 0 \\
\hline & Maximum & 0.117 & 0 & 0.254 & 0.061 & 0 & 0 \\
\hline
\end{tabular}




\begin{tabular}{|c|c|c|c|c|c|c|c|}
\hline & Std. Deviation & 0.082731 & 0 & 0.011314 & 0.027577 & 0 & 0 \\
\hline & Std. Error of Mean & 0.0585 & 0 & 0.008 & 0.0195 & 0 & 0 \\
\hline & $\begin{array}{l}\text { WHO maximum } \\
\text { permissible limit }\end{array}$ & 0.5 & 0.01 & 0.05 & 0.003 & 0.05 & 0.07 \\
\hline & $\begin{array}{l}\text { SON maximum } \\
\text { permissible limit }\end{array}$ & 1 & 0.01 & 3 & 0.003 & 0.05 & 0.02 \\
\hline & $\begin{array}{c}\text { EPA maximum } \\
\text { permissible limit }\end{array}$ & 1.3 & 0.015 & 0.05 & 0.005 & 0.1 & 0.1 \\
\hline \multirow{8}{*}{ Jan., 2016} & Mean & 0 & 0 & 0.385 & 0.0205 & 0 & 0 \\
\hline & Minimum & 0 & 0 & 0.307 & 0.02 & 0 & 0 \\
\hline & Maximum & 0 & 0 & 0.463 & 0.021 & 0 & 0 \\
\hline & Std. Deviation & 0 & 0 & 0.110309 & 0.000707 & 0 & 0 \\
\hline & Std. Error of Mean & 0 & 0 & 0.078 & 0.0005 & 0 & 0 \\
\hline & $\begin{array}{l}\text { WHO maximum } \\
\text { permissible limit }\end{array}$ & 0.5 & 0.01 & 0.05 & 0.003 & 0.05 & 0.07 \\
\hline & $\begin{array}{l}\text { SON maximum } \\
\text { permissible limit }\end{array}$ & 1 & 0.01 & 3 & 0.003 & 0.05 & 0.02 \\
\hline & $\begin{array}{l}\text { EPA maximum } \\
\text { permissible limit }\end{array}$ & 1.3 & 0.015 & 0.05 & 0.005 & 0.1 & 0.1 \\
\hline \multirow{7}{*}{ Feb., 2016} & Mean & 0 & 0 & 0.274 & 13.623 & 0.6515 & 0 \\
\hline & Minimum & 0 & 0 & 0 & 0 & 0 & 0 \\
\hline & Maximum & 0 & 0 & 0.548 & 27.246 & 1.303 & 0 \\
\hline & Std. Deviation & 0 & 0 & 0.387495 & 19.265831 & 0.92136 & 0 \\
\hline & Std. Error of Mean & 0 & 0 & 0.274 & 13.623 & 0.6515 & 0 \\
\hline & $\begin{array}{l}\text { WHO maximum } \\
\text { permissible limit }\end{array}$ & 0.5 & 0.01 & 0.05 & 0.003 & 0.05 & 0.07 \\
\hline & $\begin{array}{c}\text { SON maximum } \\
\text { permissible limit }\end{array}$ & 1 & 0.01 & 3 & 0.003 & 0.05 & 0.02 \\
\hline
\end{tabular}




\begin{tabular}{|c|c|c|c|c|c|c|c|}
\hline & $\begin{array}{l}\text { EPA maximum } \\
\text { permissible limit }\end{array}$ & 1.3 & 0.015 & 0.05 & 0.005 & 0.1 & 0.1 \\
\hline \multirow{8}{*}{ Mar., 2016} & Mean & 0 & 0 & 0.3145 & 0.961 & 0 & 0 \\
\hline & Minimum & 0 & 0 & 0.28 & 0.01 & 0 & 0 \\
\hline & Maximum & 0 & 0 & 0.349 & 1.912 & 0 & 0 \\
\hline & Std. Deviation & 0 & 0 & 0.04879 & 1.344917 & 0 & 0 \\
\hline & Std. Error of Mean & 0 & 0 & 0.0345 & 0.951 & 0 & 0 \\
\hline & $\begin{array}{l}\text { WHO maximum } \\
\text { permissible limit }\end{array}$ & 0.5 & 0.01 & 0.05 & 0.003 & 0.05 & 0.07 \\
\hline & $\begin{array}{c}\text { SON maximum } \\
\text { permissible limit }\end{array}$ & 1 & 0.01 & 3 & 0.003 & 0.05 & 0.02 \\
\hline & $\begin{array}{l}\text { EPA maximum } \\
\text { permissible limit }\end{array}$ & 1.3 & 0.015 & 0.05 & 0.005 & 0.1 & 0.1 \\
\hline \multirow{8}{*}{ Apr., 2016} & Mean & 0.05 & 0.1315 & 1.986 & 0 & 0 & 0 \\
\hline & Minimum & 0.041 & 0 & 1.678 & 0 & 0 & 0 \\
\hline & Maximum & 0.059 & 0.263 & 2.294 & 0 & 0 & 0 \\
\hline & Std. Deviation & 0.012728 & 0.185969 & 0.435578 & 0 & 0 & 0 \\
\hline & Std. Error of Mean & 0.009 & 0.1315 & 0.308 & 0 & 0 & 0 \\
\hline & $\begin{array}{l}\text { WHO maximum } \\
\text { permissible limit }\end{array}$ & 0.5 & 0.01 & 0.05 & 0.003 & 0.05 & 0.07 \\
\hline & $\begin{array}{l}\text { SON maximum } \\
\text { permissible limit }\end{array}$ & 1 & 0.01 & 3 & 0.003 & 0.05 & 0.02 \\
\hline & $\begin{array}{l}\text { EPA maximum } \\
\text { permissible limit }\end{array}$ & 1.3 & 0.015 & 0.05 & 0.005 & 0.1 & 0.1 \\
\hline \multirow{3}{*}{ May, 2016} & Mean & 0.3125 & 1.943 & 0.202 & 0.055 & 0.32 & 0 \\
\hline & Minimum & 0.293 & 1.166 & 0.153 & 0.05 & 0.1 & 0 \\
\hline & Maximum & 0.332 & 2.72 & 0.251 & 0.06 & 0.54 & 0 \\
\hline
\end{tabular}




\begin{tabular}{|c|c|c|c|c|c|c|c|}
\hline & Std. Deviation & 0.027577 & 1.098844 & 0.069296 & 0.007071 & 0.311127 & 0 \\
\hline & Std. Error of Mean & 0.0195 & 0.777 & 0.049 & 0.005 & 0.22 & 0 \\
\hline & $\begin{array}{l}\text { WHO maximum } \\
\text { permissible limit }\end{array}$ & 0.5 & 0.01 & 0.05 & 0.003 & 0.05 & 0.07 \\
\hline & $\begin{array}{l}\text { SON maximum } \\
\text { permissible limit }\end{array}$ & 1 & 0.01 & 3 & 0.003 & 0.05 & 0.02 \\
\hline & $\begin{array}{l}\text { EPA maximum } \\
\text { permissible limit }\end{array}$ & 1.3 & 0.015 & 0.05 & 0.005 & 0.1 & 0.1 \\
\hline \multirow{8}{*}{ May, 2016} & Mean & 0.3125 & 1.943 & 0.202 & 0.055 & 0.32 & 0 \\
\hline & Minimum & 0.293 & 1.166 & 0.153 & 0.05 & 0.1 & 0 \\
\hline & Maximum & 0.332 & 2.72 & 0.251 & 0.06 & 0.54 & 0 \\
\hline & Std. Deviation & 0.027577 & 1.098844 & 0.069296 & 0.007071 & 0.311127 & 0 \\
\hline & Std. Error of Mean & 0.0195 & 0.777 & 0.049 & 0.005 & 0.22 & 0 \\
\hline & $\begin{array}{l}\text { WHO maximum } \\
\text { permissible limit }\end{array}$ & 0.5 & 0.01 & 0.05 & 0.003 & 0.05 & 0.07 \\
\hline & $\begin{array}{c}\text { SON maximum } \\
\text { permissible limit }\end{array}$ & 1 & 0.01 & 3 & 0.003 & 0.05 & 0.02 \\
\hline & $\begin{array}{l}\text { EPA maximum } \\
\text { permissible limit }\end{array}$ & 1.3 & 0.015 & 0.05 & 0.005 & 0.1 & 0.1 \\
\hline \multirow{5}{*}{ Total } & Mean & 0.08129 & 0.29021 & 0.48771 & 1.22508 & 0.24771 & 0.21033 \\
\hline & Minimum & 0 & 0 & 0 & 0 & 0 & 0 \\
\hline & Maximum & 0.332 & 2.72 & 2.294 & 27.246 & 1.303 & 1.932 \\
\hline & Std. Deviation & 0.087119 & 0.635463 & 0.535367 & 5.556006 & 0.341266 & 0.572036 \\
\hline & Std. Error of Mean & 0.017783 & 0.129713 & 0.109281 & 1.134115 & 0.069661 & 0.116766 \\
\hline
\end{tabular}


Table 6: Pearson correlation coefficient of ions over the sampling time

\begin{tabular}{|c|c|c|c|c|c|c|c|c|c|c|}
\hline & $\begin{array}{c}\mathrm{NO}_{3}^{-} \\
(\mathrm{mg} / \mathrm{L})\end{array}$ & $\begin{array}{c}\mathrm{PO}_{4}{ }^{3-} \\
(\mathrm{mg} / \mathrm{L})\end{array}$ & $\begin{array}{c}\mathrm{SO}_{4}{ }^{2-} \\
(\mathrm{mg} / \mathrm{L})\end{array}$ & $\mathrm{Cl}^{-}(\mathrm{mg} / \mathrm{L})$ & $\underset{(\mathrm{mg} / \mathrm{L})}{\mathrm{Cu}}$ & $\begin{array}{c}\mathbf{P b} \\
(\mathbf{m g} / \mathrm{L})\end{array}$ & $\begin{array}{c}\mathrm{Zn} \\
(\mathrm{mg} / \mathrm{L})\end{array}$ & $\underset{(\mathbf{m g} / \mathrm{L})}{\mathrm{Cd}}$ & $\underset{(\mathrm{mg} / \mathrm{L})}{\mathrm{Cr}}$ & $\mathrm{Ni}(\mathrm{mg} / \mathrm{L})$ \\
\hline \multirow{2}{*}{$\begin{array}{l}\mathrm{NO}_{3}{ }^{2-} \\
(\mathrm{mg} / \mathrm{L})\end{array}$} & 1 & $.636^{* *}$ & -0.043 & 0.216 & 0.177 & 0.044 & -0.023 & -0.139 & -0.071 & $.577^{* *}$ \\
\hline & & 0.001 & 0.843 & 0.311 & 0.407 & 0.838 & 0.915 & 0.519 & 0.743 & 0.003 \\
\hline \multirow{2}{*}{$\begin{array}{c}\mathrm{PO}_{4}{ }^{3-} \\
(\mathrm{mg} / \mathrm{L})\end{array}$} & $.636^{* *}$ & 1 & 0.012 & $.654^{* *}$ & -0.195 & -0.179 & -0.117 & -0.126 & -0.129 & 0.34 \\
\hline & 0.001 & & 0.956 & 0.001 & 0.361 & 0.402 & 0.587 & 0.559 & 0.547 & 0.104 \\
\hline \multirow{2}{*}{$\begin{array}{c}\mathrm{SO}_{4}^{2-} \\
(\mathrm{mg} / \mathrm{L})\end{array}$} & -0.043 & 0.012 & 1 & 0.326 & -0.31 & -0.299 & $.572^{* *}$ & 0.315 & -0.061 & -0.332 \\
\hline & 0.843 & 0.956 & & 0.121 & 0.14 & 0.157 & 0.004 & 0.133 & 0.778 & 0.113 \\
\hline \multirow{2}{*}{$\begin{array}{c}\mathrm{Cl}^{-} \\
(\mathrm{mg} / \mathrm{L})\end{array}$} & 0.216 & $.654^{* *}$ & 0.326 & 1 & -0.002 & -0.01 & -0.166 & 0.057 & -0.041 & -0.136 \\
\hline & 0.311 & 0.001 & 0.121 & & 0.994 & 0.962 & 0.439 & 0.791 & 0.848 & 0.528 \\
\hline \multirow{2}{*}{$\begin{array}{c}\mathrm{Cu} \\
(\mathrm{mg} / \mathrm{L})\end{array}$} & 0.177 & -0.195 & -0.31 & -0.002 & 1 & $.824^{* *}$ & -0.074 & -0.211 & 0.158 & -0.004 \\
\hline & 0.407 & 0.361 & 0.14 & 0.994 & & 0 & 0.733 & 0.321 & 0.462 & 0.984 \\
\hline \multirow{2}{*}{$\begin{array}{c}\mathrm{Pb} \\
(\mathrm{mg} / \mathrm{L})\end{array}$} & 0.044 & -0.179 & -0.299 & -0.01 & $.824^{* *}$ & 1 & 0.052 & -0.102 & 0.234 & -0.175 \\
\hline & 0.838 & 0.402 & 0.157 & 0.962 & 0 & & 0.81 & 0.634 & 0.27 & 0.413 \\
\hline \multirow{2}{*}{$\begin{array}{c}\mathrm{Zn} \\
(\mathrm{mg} / \mathrm{L})\end{array}$} & -0.023 & -0.117 & $.572^{* *}$ & -0.166 & -0.074 & 0.052 & 1 & 0.019 & -0.039 & -0.145 \\
\hline & 0.915 & 0.587 & 0.004 & 0.439 & 0.733 & 0.81 & & 0.929 & 0.857 & 0.5 \\
\hline \multirow{2}{*}{$\begin{array}{c}\mathrm{Cd} \\
(\mathrm{mg} / \mathrm{L})\end{array}$} & -0.139 & -0.126 & 0.315 & 0.057 & -0.211 & -0.102 & 0.019 & 1 & $.648^{* *}$ & -0.085 \\
\hline & 0.519 & 0.559 & 0.133 & 0.791 & 0.321 & 0.634 & 0.929 & & 0.001 & 0.694 \\
\hline \multirow{2}{*}{$\begin{array}{c}\mathrm{Cr} \\
(\mathrm{mg} / \mathrm{L}) \\
\end{array}$} & -0.071 & -0.129 & -0.061 & -0.041 & 0.158 & 0.234 & -0.039 & $.648^{* *}$ & 1 & 0.286 \\
\hline & 0.743 & 0.547 & 0.778 & 0.848 & 0.462 & 0.27 & 0.857 & 0.001 & & 0.176 \\
\hline \multirow{2}{*}{$\begin{array}{c}\mathrm{Ni} \\
(\mathrm{mg} / \mathrm{L})\end{array}$} & $.577^{* *}$ & 0.34 & -0.332 & -0.136 & -0.004 & -0.175 & -0.145 & -0.085 & 0.286 & 1 \\
\hline & 0.003 & 0.104 & 0.113 & 0.528 & 0.984 & 0.413 & 0.5 & 0.694 & 0.176 & \\
\hline
\end{tabular}

**. Correlation is significant at the 0.01 level (2-tailed). 


\section{Conclusion}

The analysis of the water quality parameters of the upstream and downstream of the river show that $\mathrm{pH}$, temperature, TDS, TSS, TS, BOD, total alkalinity and chloride values exceeded the guidelines values of WHO, SON and EPA during the dry season and within the permissible limits during the rainy season. The EC, total hardness, sulphate and nitrate were within the range of standard values while phosphate and turbidity exceeded the permissible standards throughout the sampling period. The downstream of the river had higher values for some of these parameters compared to the upstream; this revealed that the petroleum depot waste water released into the river resulted to the high value in the downstream of the river. Thus, it can be concluded that the characteristics of this water body was influenced by seasonal variations and load of effluents discharged. It is note-worthy that the levels of $\mathrm{Pb}, \mathrm{Cd}, \mathrm{Zn}, \mathrm{Ni}, \mathrm{Cu}$ and $\mathrm{Cr}$ in the river body are particularly high enough to cause public concerns.

\section{References:}

1. Abdus-Salam, N., Adekola, F. A. \& Apata, A. O. (2010). A physicochemical assessment of water quality of oil producing area of Ilaje, Nigeria. Advance in Natural and Applied Science, 4(3), 333344.

2. Adewuyi, G. O., Etchie, O. T. \& Ademulegun, O. T. (2011). Determination of total petroleum hydrocarbons and heavy metals in surface water and sediment of Ubeji River, Warri, Nigeria. Bioremediation, Biodiversity and Bioavailability, 5(1), 46-51.

3. Akporido, S .O. \& Asagba, S. O. (2013). Quality characteristics of soil close to the Benin River in the vicinity of a lubricating oil producing factory, Koko, Nigeria. International Journal of Soil Science, 1, 1-16.

4. Antai, S. P., Iwatt, G. D. \& Agbor, R. B. (2016). Interlocation comparison physicochemical properties of polluted and unpolluted soil, water and sediment ecosystems of the Niger Delta region. World Rural Observations, 8(2), 1-9.

5. APHA (American Public Health Association), (1995). Standard Methods for the Examination of Water and Wastewater, (19th edition). APHA/AWWA/WPCF: New York; 5, 24 - 26.

6. APHA-AWWA \& WEF (American Public Health Association, American Water Works Association and Water Environmental Federation), (2005). Standard Methods for the Examination of Water and Wastewater (21st edition assessment). Academic Press: New York; 1-118. 
7. Eletta, O. A. A., Adekola, F. A. \& Aderanti, M. A. (2005). Effect of waste discharge from soft drink plant into Asa River, Ilorin, Nigeria. Journal of Applied Science and Environmental Management, 9(1), $187-190$.

8. EPA (Environmental Protection Agency), (2003). Drinking water quality standards.Edstrom Industries Waterford, Wisconsin 53185, 4230- MI4171, 1-12.

9. Etchie, T. O., Etchie, A. T. \& Adewuyi, T. O. (2011). Source identification of chemical contaminant in environmental media of rural settlement. Research Journal of Environmental Sciences, 5(9), 730-740.

10. Flura, Alam, M.A., Nima, A., Tanu, M. B. \& Khan, M. H. (2016). Physicochemical and biological properties of water from the river Meghna, Bangladesh. International Journal of Fisheries and Aquatic Studies, 4(2), 161-165.

11. Gebreyohannes, F., Gebrekidan, A., Hadera, A. \& Estifanos, S. (2015). Investigations of physicochemical parameters and its pollution implications of Elala River, Mekelle, Tigray, Ethiopia. Momona Ethiopian Journal of Science, 7(2), 240- 257.

12. Giwa, A. A., Abdus-Salam, N., Bello, I. A. \& Ibrahim, A. O. (2009). Physicochemical assessment of drinking water qualities in Ogbomoso north and south Local Government areas of Oyo State, Nigeria. International Journal of Tropical Agriculture and Food Systems, 3(4), 361-373.

13. Manikandan, R., Ezhili, N., Muthulakshmiandal, N., Paulo, J., Favas, C. \& Venkatachalam, P. (2016). Assessment of physicochemical characteristics and the level of nutrient contents as well as heavy metal ions in waters of three lakes at Coimbatore, Tamil Nadu, India. Journal of Materials and Environmental Science, 7(7), 22592266.

14. Mbaneme, F. C. N., Okoli, C. G. \& Ekweghi, C. (2013). The impact of refinery effluent in the physiochemical regime of Ekerekana Creek in Okirika Mainland, Rivers state, Nigeria. American Journal of Environment, Energy and Power Research, 1(10), 255-271.

15. Mishra, S. K. \& Jhansi, C. S. (2013). Wastewater treatment and reuse: Sustainability options. Consilience: International Journal of Sustainable Development, 10(1), 1-15.

16. Mukhetjee, B., Turner, J. \& Wrenn, B. (2011). Effect of oil composition on chemical dispersion of crude oil. International Journal of Sustainable Development, 28(7), 497-506.

17. Muniyan, M. \& Ambedkar, G. (2011). Seasonal variations in physicochemical parameters of water collected from Kedilam River, 
at VisoorCuddalore district, Tamil Nadu, India. International Journal of Environmental Biology, 1(2), 15-18.

18. Ndubuisi, O. L. \& Asia I. O. (2007). Environmental pollution in oil producing areas of the Niger Delta Basin, Nigeria: Empirical assessment of trends and people's perception. Environmental Research Journal, 1, 18-26.

19. Noortheen, A., Nagarajan, N. \& Umarani, S. (2016). Study on physicochemical parameters of water samples in and around Salem district, Tamil Nadu, India. International Journal of Current Science Research, 2(1), 219- 227.

20. OISD (Oil Industry Safety Directorate) (2012). Storage and handling of petroleum product at depots and terminals oil industry safety directorate government of India ministry of petroleum and natural gas. Standard-244, http://www.oisd.gov.in (retrieved - 09.05.2015), p. 1.

21. Owamah, H. I. (2013). Heavy metals determination and assessment in a petroleum impacted river in the Niger Delta region of Nigeria. Journal of Petroleum and Environmental Biotechnology, 4(1), 135139.

22. Rasmussen, D. V. (1976). Characterization of oil spill by capillary column gas chromatography. Analytical Chemistry, 48(11), 15361566.

23. Sahoo, M., Mahananda, M .R. \& Seth, P. (2016). Physicochemical analysis of surface and groundwater around Talcher Coal field, District Angul, Odisha, India. Journal of Geosciences and Environment Protection, 4, 26-37.

24. Sarkodie, P. A., Agyapong, D., Larbi, G. O. \& Owusu-Ansah, E. (2014). A comparative study of the quality of wastewater from Tema Oil Refinery (TOR) against EPA standards and its effect on the environment. Civil and Environmental Research, 6(6), 85-92.

25. SON (Standards Organisation of Nigeria), (2007). Nigerian standard for drinking water quality. Nigerian Industrial Standard, NIS 554, $1-30$.

26. Swingle, H. K. (2000). Standardization of chemical analysis for waters and pond meals. Food and Agriculture Organisation Fis. Rep., 4(44), 394 - 421.

27. Ubwa, S. T., Atoo, G. H., Offem, J. O., Abah, J. \& Asemave, K. (2013). An assessment of surface water pollution status around Gboko abattoir. African Journal of Pure and Applied Chemistry, 7(3), 131-138.

28. Uzoekwe, S. A. \& Oghosanine, F. A. (2011). The effect of refinery and petrochemical effluent on water quality of Ubeji creek Warri, 
Southern Nigeria. Ethiopian Journal of Environmental Studies and Management, 4(2), 106-118.

29. WHO (World Health Organization), (2005). Petroleum products in drinking-water. Background document for development of WHO Guidelines for drinking-water quality. Geneva, World Health Organization (WHO/SDE/WSH/05.08/123). 